bars, south of Weldon, the sea-bottom is totally distinct in character, being purely submarine, and formed by the action of the sea. He points out the existence of a rise and fall of the coast at different portions of its extent; this, in the most recent geological period, amounting at Charleston, South Carolina, to from 50 to $60 \mathrm{feet}$, in Maine to 200 feet, and to a still greater extent on the coast of Labrador. As a general rule, he thought there was evidence to prove that, taking a line from the centre of the continent to the centre of the sea, the sea-floor was coming up and the high elevations were coming down.Mr. Hyat states that observations made by the Coast Survey showed that the coast of Long Island Sound, and southward to New Jersey, has been sinking, while the Florida Keys are rising; and Mr. Niles remarked that, from the earliest times, in the Adirondacks and different points sou herly, there had been peninsulas corresponding in position to Florida, and that this is simply the most southern and latest of a succession from north to south.At a meeting of the New York Lyceum of Natural History, held during last autumn, Prof. Newberry, the President, exhibited the anterior portion of the cranium of a walrus which had been found during the summer at Long Branch by a gentleman whose foot struck against it while bathing. It was strongly silicified, but exhibited no appreciable difference from modern specimens. The precise age of this fossil could not, of course, be ascertained, although it is well known that its range was formerly much south of its present habitat. It is not unfrequently brought down on floating ice off the coast of Newfoundland; and although Labrador is at present the southern Jimit of its residence, it was once very abundant in the Gulf of St. Lawrence, and its remains have been found in the shell heaps of the Bay of Fundy. It is probable that the specimen exhibited by Prof. Newberry is a relic of the glacial period, although it was suggested that it might have been of the tertiary age, which probably cannot be verified. Other specimens of similar character are recorded as having been found on Martha's Vin eyard; in Monmouth Co., New Jersey; and in Accomac Co., Virginia - We have already referred to the detection of an ancient bone cave near Phœnixville, Pennsylvania, and about twenty-five miles north-west of Philadelphia, and to the interest which has attached to this discovery. Since our last account Prof. Cope has been actively engaged in the investigation of the collection, and already reports the existence of about thirty species of vertebrates, together with numerous plants and insects. All of these, so far as known, are probably of extinct species, although their precise relationships have not yet been fully worked out. Among the reptiles were tortoises and serpents, and of birds there was a turkey and a snipe. The mammals, as Prof. Cope anticipated, were most numerous, these including two carnivorous animals of large size, one of them a cat, and the other a bear, previously described by Dr. Leidy, of a remarkable type, and totally distinct from the cave bear, or any living species of either Europe or America. At least three species of sloths were discovered, mostly of gigantic size, one of them a species of Megalonyx, and two of Mylodon. Besides these, there were some ruminating animals, tapirs, and a small horse. With the other remains were the teeth and tusks of the mastodon. The fissure in which the bones were found was forty feet deep and fifteen feet wide ; the length as yet has not been determined. Above the deposit of bones the cave was filled with washings of the Triassic age from the neighbouring hills.

\section{SCIENCE AT OXFORD}

THE following courses of lectures in Science are announced for the ensuing term :- The Regius Professor of Medicine (Dr. Acland) will continue his clinical instruction at the Infirmary, on Tuesdays and Saturdays, beginning on Tuesday, May 2, at II A.M. The Linacre Professor of Anatomy and Physiology (Dr. Rolleston) proposes to form classes for practical instruction in anatomy and physiology, as in former terms. Persons are invited to come to the anatomical department in the New Museum on two mornings of the week for study and demonstration, and to lectures on Saturdays at I P.M., and at such other times as may be hereafter arranged. The Sedleian Professor of Natural Philosophy (the Rev. Bartholomew Price) will give a course of lectures on the Solution of Problems in Applied Mathematics. The course will begin at I P.M. on Thursday, April 20, in the lecture-room, upper corridor south, Museum. The Savilian Professor of Astronomy (the Rev. C. Pritchard) will give a lecture early in the present term on the recent solar eclipse. He will also be ready to assist members of the University in their astronomical studies, "sine ulta solennitate." The Savilian Professor of Geometry (Mr. Henry Smith) will continue his lectures on the Anharmonic Properties of Figures. $\mathrm{He}$ will also give a course of lectures on Geometry of Three Dimensions. The Professor of Geology (Mr. J. Phillips) will begin a course of lectures on Monday, April 24 , at 12 o'clock, and continue them at the same hour on succeeding Wednesdays and Mondays, in the New Museum. The lectures are arranged to present a systematic view of the more remarkable groups of organic remains, especially in the extinct groups. The Professor of Experimental Philosophy (Mr. R. B. Clifton) has given notice that the Physical Laboratory of the University will be open daily for instruction in practical physics, from IO A.M. to 4 P.M., on and after Wednesday, April r9. The fee for working three days a week during the term is $3 l$. The Professor of Chemistry (Sir B. Brodie) has given notice that the Demonstrator in Chemistry will deliver a course of lectures on Chemistry on Tuesdays and Saturdays, at II A.M., commencing Tuesday, April 25. These lectures will be in continuation of the course of the Professor of Chemistry last term, and will commence with the element phosphorus and its combinations. The Professor of Botany (Mr. Lawson) will give a course of lectures on Structural and Physiological Botany. The Hope Professor of Zoology (Mr. Westwood) proposes to give a short course of lectures on the Articulated Animals.

\section{SETTLE CAVE EXPLORATION}

$A^{T}$ the last meeting of the Settle Cave Exploration A Committee, the report of the excavation of the Victoria Cave, up to December 3Ist, 1870, by Mr. Boyd Dawkins, was read.

The results of the exploration are full of interest, and bid fair to throw light on the social condition of the Romano-Celtic inhabitants of Ribblesdale after the withdrawal of the Roman legions. The committee placed the superintendence of their exploration in the charge of $\mathrm{Mr}$. Jackson, the discoverer of the cave, and began work with the kind permission of the owner (Mr. Stackhouse), by clearing away a mass of debris, which very nearly blocked up the lower entrance and formed a horizontal plateau extending some thirty feet from the solid rock. On the surface there was a stratum of angular stones which had fallen from the weathered face of the rock above, and passed into the cave at the bottom of the Attermire ravine. Below was the layer which furnished traces of man. Mixed with charcoal there were large quantities of the bones and teeth of the Celtic short-horn (Bos longifrons), goat, and horse, and a few remains of red deer and roe deer, which were evidently the refuse of human food. There were also fragments of pottery, bone pins, and various nondescript articles in antler and bone, stone pot-boilers, and two perforated discs of stone which had been used as spindle-whorls. As this layer passed into the cave, it rose to the surface and continued to 